\title{
Europski uzori i hrvatski jezični priručnici u 18. stoljeću
}

\section{Uvod}

Nastajanje novih pisanih djela uvijek je i nastavljanje na već postojeće. U tome nema ničega spornoga. Riječ je o svojevrsnoj evoluciji, ono napisano poslije uzet će najbolje od onoga prije i dodati nešto svoje, a s vremenom, ako je uspješno, i samo će poslužiti nastajanju nekoga novoga djela. Taj ćemo proces, koji je ovdje samo načelno skiciran, pratiti na hrvatskim jezičnim priručnicima u 18. stoljeću. ${ }^{1}$ Djelo na koje se nastavlja, koje služi pri sastavljanju novoga djela, može biti uzor ili izvor, ponekad oboje istodobno. Pod izvorima razumijevamo djela iz kojih se posuđuje građa pri izradi rječnika ili gramatike. Izvori mogu biti književna djela iz kojih se uzimaju leme za rječnik, ali i značenja i tekstne potvrde, ako ih rječnik donosi, dok će se za gramatiku preuzimati uz riječi i veće konstrukcije poput sintagmi i rečenica, ovisi za koji će dio gramatike poslužiti. ${ }^{2} \mathrm{~S}$ druge strane, kad govorimo o uzorima, mislimo na djela koja

1 O toj sam temi izlagala na Prvom bosanskohercegovačkom slavističkom kongresu, Sarajevo 26-28.5.2011.

${ }^{2}$ Usporedi na primjer Sintaksu hrvatskoga književnoga jezika Radoslava Katičića u kojoj je autor oprimjerio sintaktičke opise građom iz hrvatskoga književnoga jezika od polovice 18. stoljeća. 
služe kao model prema kojemu su nastala druga djela. Model može posredovati raznolike sadržaje, primjerice može se od njega preuzeti koncepcija djela, metoda opisa jezičnih činjenica, tvorbeni uzorci, stajališta o poimanju naravi jezika i slično. Utjecaji su mnogobrojni.

Jedan od najutjecajnijih rječnika u europskoj leksikografiji bio je poznati rječnik firentinske akademije Crusce pod naslovom Vocabolario degli Accademici della Crusca. ${ }^{3}$ Taj je rječnik poslužio pri obradi natuknica i donošenju književnih potvrda kao svojevrsni model mnogim rječnicima, ponajprije onima koje su izrađivale nacionalne akademije diljem Europe poput francuske, španjolske ili švedske. ${ }^{4}$ Isto tako, jedna od najutjecajnih školskih gramatika svakako je bila Alvaresova gramatika latinskoga jezika pod naslovom De institutione gramatica libri tres koja je prvi put izišla 1572. godine u Lisabonu, a u nekoliko stoljeća doživjela je preko četristo izdanja. Alvaresova je gramatika bila propisana kao obvezatni udžbenik za učenje latinskoga jezika u isusovačkim školama, no utjecaj se širio i na druge redovničke zajednice, a i izvan latinskoga jezika. ${ }^{5}$

Dakle, postoje uzori i izvori, a nerijetko jedno djelo istodobno može biti i uzor i izvor nekomu drugomu djelu. Kako je već rečeno, izvor rječnicima ili gramatikama zapravo jest korpus, odnosno građa. Najčešće je riječ o književnim djelima, što pak ovisi o koncepciji rječnika, ali i o koncepciji književnoga jezika. Tako su na primjer Della Belli kao izvor građe poslužila hrvatska književna djela 16, 17. i 18. stoljeća. Međutim, kako su hrvatski rječnici sve do samoga kraja 19. stoljeća bili višejezični, izvori za druge jezike nisu bila književna (ili neka druga pisana) djela iz toga/tih jezika/â, već zapravo rječnici toga/tih jezika/â. Tako je bilo uobičajeno navoditi latinske autore u kojih je potvrđen leksik koji se donosi u rječniku, no osvrnemo li se samo na Jambrešić-Sušnikov predgovor u kojem se donosi više desetaka latinskih pisaca, lako možemo posumnjati da su ta dvojica rječnik sastavljala vadeći leme iz Cicerona, Vergilija i mnogih drugih. Pretpostavljamo da je bila uobičajena praksa uzeti neki pouzdan rječnik s latinskom građom i jednostavno ju prepisati. ${ }^{6} \mathrm{Na}$ kraju krajeva, rječnici se obično smatraju kompilacijama i ta praksa ne umanjuje doprinos ili posao

${ }^{3}$ Prvo izdanje rječnika izišlo je 1612. godine. Objava se toga rječnika smatra početkom standardizacije uopće. O tome više usporedi u Engler 2000.

${ }^{4}$ Detaljnije o tome usp. Košutar, Tafra 2010.

${ }^{5}$ O Alvaresovoj gramatici u Hrvata usp. Štefanić 1940.

${ }^{6}$ Svi istraživači (na primjer Vladoje Dukat, Pavao Knezović, Josip Jernej, Nives Sironić-Bonefačić, Stanko Žepić i dr.) koji su se bavili pronalaženjem uzora i izvora pojedinim hrvatskim rječnicima često navode strane rječnike kao izvore za latinsku ili neku drugu građu, pa i to podupire izneseno mišljenje. 
leksikografa (Hartmann 1986). To je u starijoj hrvatskoj leksikografiji donekle i opravdano. Kako su rječnici bili višejezični, pitanje je bismo li imali ijedan rječnik da se svaki rječnik radio «pješice». Dakle, i rječnici mogu biti izvori. To će se pitanje, posebno europskih uzora i izvora, promotriti na hrvatskim jezičnim priručnicima 18. stoljeća. Pod jezičnim priručnicima razumijemo gramatike, rječnike i pravopise. A što čini hrvatske jezične priručnike u 18. stoljeću? Tafra i Fink (2008) postavile su dva kriterija koja trebaju odrediti što čini hrvatsku leksikografiju. Prvi je primijenjen na razdoblje do 1918, a drugi nakon 1918. godine. Prema njima ako je u djelu zastupljen hrvatski leksik, djelo pripada povijesti hrvatske leksikografije, a to vrijedi ako je riječ o djelima nastalima do 1918. godine. Taj je kriterij jedini logičan za to razdoblje jer, kako autorice objašnjavaju, ne može se uzeti ni autorski (mnogi autori nisu bili Hrvati), ni nacionalni, ni teritorijalni kriterij. Ovdje se prihvaća njihov kriterij te se smatra da bi se on mogao postaviti i za ostale jezične priručnike. Sve rečeno za rječnike stoji i za gramatike i za pravopise. Nisu svi autori Hrvati, većina ih je tiskana izvan područja Hrvatske, a neki su i napisani vani. Jedino se može gledati po hrvatskom jeziku u njima. Hrvatski je jezik ili predmet opisa, a ta su djela sve do Starčevićeve gramatike iz 1812. godine na latinskom, talijanskom ili njemačkom jeziku, ili je predmet opisa neki drugi jezik, latinski, njemački ili talijanski, pa je hrvatski jezik metajezik tih gramatika ili pravopisa.

\section{Hrvatski jezični priručnici u 18. stoljeću}

Najprije ćemo dati pregled uzora i izvora, ponajprije europskih, hrvatskim jezičnim priručnicima. Dosad su manje-više istraženi uzori i izvori starijim hrvatskim jezičnim priručnicima, više izvori nego uzori. Domaća su se istraživanja, osim vrijednih izuzetaka, usmjerila uglavnom na domaće uzore i izvore. Ovdje ne želimo umanjiti doprinos domaćih uzora, već se promatranje želi proširiti izvan teritorijalnih granica, pa i preko usko kroatističkih okvira. Poznato je da su gramatike latinskoga jezika diljem Europe pisane po uzoru na Alvaresovu gramatiku, stoljećima su pisane preradbe po cijeloj Europi, pa tako i na hrvatskom području. U 18. stoljeću pod Alvaresovim su utjecajem gramatike latinskoga pisali Toma Babić, Lovro Šitović, Marijan Lanosović i Josip Jurin. Alvares je utjecao i na gramatike hrvatskoga jezika. Naime, kako je Katičić (1981) pokazao, Alvares je uz Alda Manuzija i Donata bio glavnim uzorom Kašićevim Institutiones linguae Illlyricae. Tvrdi se da su se svi gramatičari do kraja 19. stoljeća ugledali na Kašića, pa se Alvaresova gramatika latinskoga jezika posredno i neposredno stoljećima provlačila kroz mnoge gramatike 
hrvatskoga jezika. To je vjerojatno jedan od mnogih razloga velikoga utjecaja latinskoga jezika na hrvatski na mnogim jezičnim razinama.

Kako se mijenjala politička uprava, mijenjao se i jezik moći. Iako je latinski i dalje službeni jezik, pojavila se potreba za priručnicima na njemačkom jeziku u kontinentalnom dijelu, dok je na obali latinski imao suživot uz hrvatski i talijanski. Rječnici su već prije donosili njemački, pa i mađarski kao ciljne jezike, kao što je u Jambrešić-Sušnikovu rječniku iz 1742, a u gramatikama će se pojaviti tek u drugoj polovici stoljeća, i to prvo u slavonskim priručnicima, a nakon uvođenja novoga školskoga sustava Ratio educationis i u kajkavskom dijelu. Do polovice 18. stoljeća postoje dvije gramatike latinskoga jezika s hrvatskim metajezikom, riječ je o Babićevoj ${ }^{7}$ i Šitovićevoj ${ }^{8}$ gramatici, te postoji i jedna gramatika hrvatskoga s talijanskim kao metajezikom koju je napisao Della Bella ${ }^{9}$. U drugoj polovici objavljuju se Tadijanovićeva ${ }^{10}$, Relkovićeva ${ }^{11}$ i Lanosovićeva ${ }^{12}$ gramatika. Riječ je o dvojezičnim njemačko-hrvatskim gramatikama. Lanosović je autor i latinske gramatike, a Jurin ${ }^{13}$ trojezične latinsko-talijansko-hrvatske.

Kao što je već spomenuto, pri pisanju latinskih gramatika glavni je uzor Alvaresova gramatika. Sve gramatike imaju i aneksne rječnike, a leme se najčešće

7 Bibliografski su podaci o djelima općepoznati i dostupni, pa ih ne donosimo. O Babiću i njegovoj gramatici usporedi ove radove: Šetka 1967, Ko sor 1981, Kolenić 2000, Demo 2004, te radove koji su 2002. godine objavljeni u Zborniku o Tomi Babiću.

8 Za literaturu o Šitoviću vidi ove radove: Ku na 1961, Raguž 1978, Knezović 1988, Gostl 1998, Knezović i Demo 2005, te radove koji su objavljeni u Zborniku o Lovri Šitoviću iz 2009. godine.

9 O Della Belli je pisano mnogo radova, a najviše o njegovu rječniku. Vidi radove u zborniku Isusovac Ardelio della Bella (1655-1737), članke u devetnaestom broju Filologije (1991), te radove Nives Sironić-Bonefačić (1992), Branke Tafre (1990) i drugih.

10 O Tadijanoviću usp. radove: Jonke 1966, Tafra 1981, Putanec 1981, Häusler 1992, Žepić 1998, Kolenić 2003 i Despot 2005.

${ }^{11}$ O Relkoviću i njegovu djelu, ponajprije književnom prosvjetiteljskom radu, mnogo je pisano. Njemu u čast održana su dva znanstvena skupa čiji su radovi objavljeni u dvjema knjigama: Vrijeme i djelo Matije Antuna Reljkovića (1991) i Matija Antun Relković i Slavonija 18. stoljeća (2000).

${ }^{12}$ Lanosović je gotovo profesionalni jezikoslovac ako se za nekoga u 18. stoljeću može tako uopće reći. Autor je nekoliko gramatika, sudjelovao je u radu pravopisne komisije, a dopunjavao je i Stullijev latinsko-talijansko-hrvatski rječnik njemačkim ekvivalentima. Lanosoviću u čast održan je znanstveni skup u Slavonskom Brodu 1982, a radovi se s toga skupa mogu naći u Zborniku o Marijanu Lanosoviću (1985).

13 O njegovu jezikoslovnom radu usporedi radove Marka Kosor a $(1953,1955,1957)$ te radove objavljene u zborniku Jezikoslovac fra Josip Jurin (1999). 
donose iz Calepina. Kao uzori slavonskim gramatikama poslužili su mahom priručnici iz njemačkoga govornoga područja. Za Tadijanovićevo djelo još nije pronađen glavni uzor, no smatra se da su za neke dijelove kao uzor mogli poslužiti konverzacijski priručnici koji su tada u Europi bili popularni, ili pak koja njemačko-francuska ili njemačko-talijanska gramatika autorâ Pierrea Rondeaua ili Veneronija (Putanec 1981; Tafra 1981; Häusler 1992). Relković sam navodi neke svoje uzore, a posebno naglašava djelo Institutiones linguae Germanicae polihistora Mateja Bela (Mathius Belius). Tako Relković na jednom mjestu kaže: «Ovo dakle za sada neka bude od Nimacske Ortographiae dosta ukazano, tko xeli vishje imati, neka shtie Mathiae Belii Inst. Linguae Germanicae, i ostale Nimacske Authore» (Relković 1767, 51). Lanosović je pak svoj priručnik Neue Einleitung zur slavonischen Sprache, kako je Nyomárkay (2000) dokazao, napisao prema Felbigerovim udžbenicima koji su bili propisani za cijelu Monarhiju. Poznato je da je Felbiger udžbenike radio prema Gottschedovu djelu Grundlegung einer deutschen Sprachkunst (1748), koje se pak smatra normativnim priručnikom njemačkoga jezika do Adelunga (Häusler 1992). Latinsku je gramatiku najvjerojatnije priredio prema nekoj prethodnoj Alvaresovoj preradbi (Ptičar 1985). Jurin sam nabraja uzore i izvore prema kojima je izradio svoju Slovkinju, a na prvom mjestu opet dolazi Alvares. Od poznatijih spominje i Alda Manuzija, domaće prethodnike Babića i Levakovića te neke leksikografe (Kosor 1953). Od kajkavskih gramatika treba spomenuti Nemsku gramatiku Antuna Rajspa iz 1771. godine te Szentmártonyjevu Einleitung zur kroatischen Sprachlehre für Teutsche iz 1783. godine. Kod Rajspa se prepoznaje metodički utjecaj Jana Komenskoga (Häusler 2002), a od jezikoslovnih Gottsched kojega sam Rajsp u djelu spominje, kao u primjerima: "Gottsched odgovarja; dasze tato nikakva obchinszka regula dati nemore ...», ili pak «Navuchitel nemskoga jezika naiglaszovitessi (Gottsched, Popowitsch) pridavnu rechvu drugom redu ...» (Rajsp 1771, 15 prema Žepić 1998, 46). Szentmártony je djelo pripremio prema Felbigerovu udžbeniku koji je bio propisan za novi školski sustav. Spomenimo i da je to prva tiskana gramatika kajkavskoga književnoga jezika. ${ }^{14}$

Prije nego što krenemo na leksikografske uzore, nekoliko napomena. Kako je to stoljeće bilo leksikografski iznimno plodno, ovdje ćemo se osvrnuti na nekoliko naslova koja mogu poslužiti kao reprezentativni primjerci. Glavni je leksikografski uzor hrvatskim jezičnim priručnicima svakako bio Calepin. Naime, svi su se domaći leksikografi koristili nekim od izdanja njegova rječnika.

14 O Szentmártonyju usp. Jembrih 1990. 
Della Bella nije odolio utjecaju Cruscina Vocabolarija (Sironić-Bonefačić 1990), kao uostalom ni cijela Europa, prema kojemu sastavlja svoj talijansko-latinsko-ilirski rječnik. ${ }^{15}$ Kontinentalci Belostenec ${ }^{16}$ te Sušnik i Jambrešić ${ }^{17}$ pod jačim su utjecajem njemačke leksikografije. Dukat $(1923,1925,1928)$ i Žepić (1992) pokazali su da su se uz Calepinove preradbe koristili i rječnicima Johana Frisiusa, Adama Friedricha Kirscha, Georga Matije Königa, ali i pokojim drugim «nejezikoslovnim» autorom poput Konrada Gesnera, njemačkoga Plinija, čija djela predstavljaju početak moderne zoologije, ili djelima Jana Komenskoga. Sami se leksikografi u svojim djelima pozivaju na poznate europske uzore ili pak donose popise citiranih djela, najčešće književnih. Najdalje je u tome otišao Joakim Stulli ${ }^{18}$ koji je u popisu citiranih djela zabilježio preko 150 naslova kojima se služio pri izradi, a na tom se popisu uz mnoga književna djela nalaze i mnoge gramatike, domaće i strane, poput slovenske, poljske ili češke, potom različiti slavenski rječnici, što potvrđuju i brojni slavenizmi u rječničkoj građi, ali i drugi europski rječnici te djela već spomenutoga Jana Komenskoga.

Ovdje su samo nabrojena najvažnija imena europskih uzora, bez detaljnoga uvida u to kako su ona utjecala na hrvatske jezične priručnike u 18. stoljeću. Kratko se samo može reći da u pronalaženju djela u koja su se ugledali često pomažu sami autori kad donose popis svojih uzora i djela koje citiraju, a koje u popisu ne odvajaju. Nije rijetkost da se i u samom djelu pozivaju na autoritete kako bi pojačali svoje tvrdnje, kao što smo to vidjeli kod Rajspa, a sličnih tvrdnji ima i u drugih autora. Autori i metodički upućuju čitatelja na strane autoritete ako žele naučiti više kao što smo vidjeli kod Relkovića. Još možemo spomenuti da se autori nikad ne koriste samo jednim djelom, već s više njih radeći zapravo kompilaciju manje ili više pomno birajući iz uzora i izvora što će staviti u svoje djelo.

${ }^{15}$ O Della Belli usp. radove iz bilješke 9.

16 Rječnik je Belostenec sastavio u 17. stoljeću, no on je objavljen tek 1740. godine otkad se i bilježi njegov utjecaj pa se Gazofilacij smatra djelom koje pripada i 18. stoljeću. O Gazofilaciju je napisano mnogo radova, a kao najvažnije usporedi: Fancev 1923, Dukat 1923, Dukat 1928, Vončina 1973, te radove sa znanstvenoga skupa «Ivan Belostenec i hrvatska kultura njegova doba» koji su objavljeni u časopisu Gazophylacium, god. X, br. 1-2, iz 2005. godine.

17 O njihovu rječniku usp. radove: Dukat 1905, Dukat 1925, Musulin 1959, Šojat 1992, Žepić 1992, Nyomárkay 1992. i dr.

${ }_{18}$ O Stullijevu jezikoslovnom radu napisano je mnogo radova, a najvažnije podatke donose Dukat 1929, Brlek 1987, te radovi sa znanstvenoga skupa o Joakimu Stulliju koji su objavljeni u dvanaestom broju Filologije 1984. godine. Iako su rječnici objavljeni u 19. stoljeću, sastavljeni su u 18. stoljeću i još su netiskani utjecali na druga leksikografska djela, kao i na određene jezične djelatnosti poput jezične politike Dvora krajem 18. stoljeća, pa se ti rječnici promatraju kao djela koja pripadaju i 18. stoljeću. 


\section{Hrvatski rječnici 18. stoljeća i leksikografske odrednice u kontekstu europske leksikografije}

Svi su ti uzori i izvori uvelike utjecali i na formu i na sadržaj hrvatskih jezičnih priručnika i mnogo je razina na kojima bi se to moglo pokazati. Spomenut ćemo samo jedan mali primjer pri korištenju leksikografskih odrednica u rječniku. Pod leksikografskim odrednicama razumijevamo posebne simbole i kratice koje autori upotrebljavaju kako bi se natuknica odredila gramatički, lingvostilistički, čestotno, etimološki, terminološki i tako dalje. ${ }^{19}$ Bez tih odrednica danas ne možemo zamisliti rječnike, no one nisu postojale oduvijek. Još ni u 17. i 18. stoljeću odrednice nisu bile posve uobičajene, a iako ih ima u rječnicima, njihova upotreba nije bila normirana.

U hrvatskom jezikoslovlju samo je nekoliko autora pisalo o leksikografskim odrednicama. Bratanić-Čimbur $(1979,7)$ leksikografskim odrednicama smatra «sve podatke unutar članka koji sadrže neku obavijest o morfološkim, sintaktičkim, stilističkim ili upotrebnim karakteristikama natuknice», a dijeli ih u dvije kategorije, gramatičku i upotrebnu. Gramatičke odrednice daju gramatičke informacije o leksičkoj jedinici, a najčešće se nalaze uz natuknicu, iako se mogu nalaziti i drugdje u rječničkom članku. Upotrebne odrednice dijeli dalje na stilske (npr. dijalektnost, arhaičnost, kolokvijalnost natuknice ili značenja) i područne (npr. ograničena upotreba natuknice u nekom području ljudske djelatnosti poput kemije, medicine i dr., dakle terminološke odrednice).

Iako se u svom radu bavi stilskim odrednicama, Babić je (1981) na početku dao svoju tipologiju leksikografskih odrednica. Definiciju odrednica preuzima od Bratanić-Čimbur (1979), ali daje svoju podjelu. Tako odrednice dijeli na gramatičke, etimološke, značenjske, područne (terminološke, stručne) i stilske (Babić 1981, 79). Gramatičkim se odrednicama daju gramatički podaci, primjerice, o rodu, padežima, o vidu i prijelaznosti glagola i dr., a u njih ubraja i ortoepske odrednice. Etimološkim se odrednicama određuje podrijetlo natuknice, značenjske odrednice određuju je li značenje preneseno ili

19 Leksikografske se odrednice javljaju i pod terminom upotrebne etikete (usp. Šipka 1998), što je doslovni prijevod engleskoga termina usage labels, dok npr. Zgusta (1991) za leksikografske odrednice upotrebljava termin glosa. No, Hartman n i Ja mes (2002) u svojem rječniku leksikografije razlikuju glose i oznake (label). Prema njima glosa čini dio definicije, dok oznake (odrednice) određuju natukničku riječ stilski i slično. Ovdje ćemo to sve zvati leksikografskim odrednicama. 
figurativno. Područne odrednice određuju natuknicu terminološki i stručno, a Babić ih smatra dopunom značenjskim odrednicama. Zadnju skupinu, stilske odrednice, Babić (1981) dijeli na pet podskupina: ekspresivne, slojne, dijalektne i teritorijalne, vremensko-čestotne i normativne. Uza svaku skupinu i podskupinu Babić (1981) daje i primjere odrednica, nerijetko naglašavajući kako se odrednice jedne skupine mogu promatrati i kao odrednice druge skupine s čim se svakako slažemo. Za dobru tipologiju odrednica bit će potrebno jasno odrediti kriterije s kojih se polazi.

Petrović (2002) u svom članku pod naslovom Uputnice u dvojezičnicima s hrvatskim kao polaznim jezikom govori o uputnicama i njihovu mjestu i funkciji unutar rječničkoga članka. Uputnicama se jedna natuknica upućuje na drugu, obično prihvatljiviju. Petrović (2002) uputnice ne smatra odrednicama kao ni ostala literatura koja je ovdje spomenuta, a i nešto uže promatra leksikografske odrednice nego što to gledaju drugi autori. Autorica u članku daje prijedlog sustava uputnica, a jedina od pregledanih domaćih autora daje i tehnički opis svoga predloženoga sustava u kojem, što je posebno zanimljivo, donosi i grafijske oznake. Iako su se grafijskim oznakama u rječničkim člancima koristili i stari hrvatski leksikografi, što ćemo pokazati dalje u tekstu, nismo pronašli da je netko to istraživao, odnosno da se osvrnuo uz sadržaj i na oblik odrednica ili drugih dijelova rječničkoga članka. Petrović (2002) dakle predlaže svoj sustav s grafijskim oznakama (npr. >, >> i dr.) prema kriterijima za upućivanje natuknica koji mogu biti normativni, semantički, gramatički, pravopisni itd. Autorica smatra da bi se posebnim grafijskim oznakama natuknice mogle upućivati na češći, običniji ili stilski neutralni leksem, potom na domaću riječ ili izraz i slično. Smatramo da iz rečenoga slijedi da se natuknička leksička jedinica koja se upućuje na drugu određuje kao rjeđa, neprihvatljiva, stilski ili drugačije obilježena, što te uputnice zapravo čini i odrednicama jer polaznu leksičku jedinicu i određuju. To bi pak učinilo uputnicu ujedno i odrednicom, što je i naš argument za to da se u leksikografske odrednice uvrste i uputnice, odnosno uputnice smatramo vrstom leksikografskih odrednica.

Brlobaš (2003) jedina od pregledane domaće literature obrađuje odrednice u nekom «starijem» rječniku. Riječ je o hrvatsko-talijanskom rječniku Dragutina Parčića iz 1901. godine i gramatičkim odrednicama u njemu. Autorica gramatičke odrednice detaljno analizira te ih uspoređuje s drugim izdanjima Parčićeva rječnika i s gramatičkim odrednicama u Rječniku ilirskoga i njemačkoga jezika Rudolfa Veselića iz 1853. godine. Tikvica se (2009) u svom radu usredotočila na lingvostilističke odrednice u rječnicima hrvatskoga jezika koje promatra s aspekta funkcionalne stilistike. 
Sažeto možemo reći da radova o leksikografskim odrednicama u hrvatskom jezikoslovlju nema mnogo, u posljednjih je trideset godina obljavljeno samo pet. Nekoliko je tipologija odrednica, koje se sadržajno manje-više preklapaju, a tri su se autorice bavile određenom vrstom odrednica. Ovdje se slažemo s definicijom odrednica koju je ponudila autorica Bratanić-Čimbur (1979), a držimo da se odrednicama mogu smatrati i uputnice, kako smo u tekstu pokazali. Definicija odrednica koju je dala Bratanić-Čimbur (1979) dovoljno je široka za to. Tu bismo tipologiju odrednica dopunili predlažući njihovu podjelu najprije sa sadržajnoga i formalnoga kriterija. Sadržajni je kriterij u dosadašnjoj literaturi dovoljno obrađen, tek je poneka razlika u imenovanju i broju vrsta odrednica, no zanemaruje se formalni kriterij prema kojemu se odrednice dijele prema svom grafijskom liku. Primjenom toga drugoga kriterija dobivaju se dvije glavne podjele. Odrednice mogu biti kratice i simboli u koje uključujemo i druge oznake. Iako je općenito sadržajni kriterij naravno važniji od formalnoga, s obzirom na to da je ovdje riječ o rječničkom članku koji je uvelike prostorno ograničen, formalni kriterij promatranja nekoga dijela rječničkoga članka iznimno je važan ekonomičnosti radi. ${ }^{20} \mathrm{O}$ tome dalje ovdje neće biti riječi jer to nije tema ovoga rada. Kako bi se dopunila slika uzora i izvora o kojoj je bilo riječi na početku rada i kako bi se na jednoj odabranoj metaleksikografskoj temi pokazao odnos europskih uzora i hrvatskih jezičnih priručnika u 18. stoljeću, još ćemo samo pokazati kakve su leksikografske odrednice upotrebljavali stari hrvatski leksikografi te na nekoliko odabranih primjera kako je to bilo u Europi.

Uobičajeno je danas da leksikografskomu djelu prethodi predgovor ili kakav drugi sličan tekst u kojem se, među ostalim, daju upute o tome kako čitati rječnik. To pak nije moderan izum, uputama su se koristili i stariji hrvatski leksikografi. Neki u njima, poput Belostenca ili Jambrešića i Sušnika, daju više podataka, a neki, poput Della Belle i Stullija, manje. Della Bella (1728) uz popis hrvatskih pisaca daje i popis kratica kojima se koristio. Drugo će izdanje, koje je 1785. priredio Petar Bašić, u tom dijelu biti nešto informativnije od prvoga. Među leksikografskim odrednicama u tom rječniku nalaze se različite gramatičke odrednice (vrsta riječi, rod, broj itd.), značenjske odrednice poput Metaf. (označuje da je značenje preneseno), različite odrednice koje natuknicu

${ }^{20}$ U sličnom smjeru idu i Putanečeve (1994) misli koji je uveo pojam sigliranja u hrvatsku leksikografiju što bi imalo značiti kraćenje, a riječ je o tome da jedan znak zamijeni čitavu riječ ili čak i dijelove definicije koji se često ponavljaju. Iako on izravno ne govori o leksikografskim odrednicama, autor je blizak ovoj temi jer znakovi o kojima govori jesu leksikografske odrednice i jer pažnju posvećuje upravo ograničenu prostoru rječničkoga članka. 
određuju geopolitički (Capit. za Capitale), a ima i terminoloških (T. Bot. za Termine Botanico, T. Eccl. za Termine Ecclesiastico) i etimoloških odrednica (V. Gr. za Voce Greca ili V. Pol. za Voce Pollaca i tako dalje), a tu su i neizbježne uputnice (V. za Vide, odnosno vidi).

Belostenec (1972) daje u predgovoru nekoliko uputa kako se koristiti rječnikom, odnosno što mu znače kurzivirane kratice u rječničkim člancima. Ima slovne kratice i brojeve za gramatičke odrednice, a posebno su zanimljive odrednice koje određuju prozodiju. Tako kraticom $p$. c. označava da je pretposljednji slog kratak, a $p$. $p$. da je pretposljednji slog dug. Osim gramatičkih odrednica ima i značenjskih poput Transl. i Metaph. za preneseno značenje, te odrednice kojima se riječi određuju regionalno ( $\mathrm{Scl}$. za slavonski, $\mathrm{Cr}$. za hrvatski, odnosno kajkavski, i Turc. Sc. za tursko-slavonski). Upotrebljava još i kratice za citirane autore te uputnicu $v$. za vide, odnosno vidi.

Jambrešić-Sušnikov (1992) rječnik ima najpotpunija objašnjenja u predgovoru od svih domaćih rječnika u 18. stoljeću. Čak se i predgovor ne naziva samo predgovorom već i objašnjenjem djela (Praefatio et declaratio operis). Objašnjenja se daju u osamnaest točaka, a sedma, osma, deveta, dvanaesta i četrnaesta daju objašnjenja o leksikografskim odrednicama. Jedini od domaćih autorâ upotrebljavaju uz kratice i simbole. Od simbola koriste se zvjezdicom $\left(^{*}\right)$ i križićem (†) koje postavljaju s lijeve strane natuknice. Zvjezdicom označuju riječi grčkoga podrijetla, a križićem barbarizme kako ih nazivaju. Od kratica upotrebljavaju Obsol., Inus. ili Antiq. za «starinske riječi». Terminološke odrednice donose pod kraticama Theol., Jcti., Phil. itd., a one označuju zanimanja ljudi koji ih upotrebljavaju (teolozi, pravnici, filozofi ...). Objašnjavaju i da raznolikost značenja i upotrebe razlikuju arapskim brojkama, ${ }^{21}$ a brojne sinonime kojima rječnik obiluje označuju kraticom V. Syn. pro (vidi sinonim za). Rječnik ima i značenjske odrednice Tran., Metaph. i Meton. Tu su i brojne gramatičke odrednice, a najzanimljivije su kratice za rodove njemačkih imenica. Tako im $r$. označuje njemačku imenicu muškoga, $e$. imenicu ženskoga i s. imenicu srednjega roda.

Stullijev latinsko-talijansko-hrvatski rječnik iz 1801. godine ima sasvim kratak predgovor u kojem nema nikakvih objašnjenja o leksikografskim odrednicama, a tek na kraju rječnika daje popis pisaca i djela kojima se u izradi služio. Pregledom rječničkih članaka nisu uočeni nikakvi posebni simboli kao

${ }^{21}$ Istraživanje koje je provedeno za jedan drugi rad pokazalo je da Jambrešić i Sušnik razlikuju polisemiju i homonimiju u jednoj natuknici tako da različita značenja jedne riječi, dakle polisemiju, odvajaju zarezom, a homonime obrojčavaju u jednoj natuknici. 
leksikografske odrednice osim znaka koji nalikuje donjem lijevom navodniku („), a koji stavlja uz natuknice koje obično upućuje na druge natuknice. Sličan smo simbol u sličnoj upotrebi uočili i u talijanskim rječnicima koje smo pregledali, a koji su mogli poslužiti Stulliju kao uzori ili izvori (usp. npr. Vocabolario 1751).

Da bismo upotpunili sliku o leksikografskim odrednicama u 18. stoljeću, pregledani su i neki europski rječnici iz toga vremena koji se često spominju kao uzori i izvori hrvatskima u to vrijeme. Najzanimljiviji je u tom smislu bio rječnik Adama Friedricha Kirscha pod naslovom Abudantissime Cornu Copiae Linguae Latinae et Germanice selectum iz 1718. godine. Riječ je o enciklopedijskom dvojezičnom latinsko-njemačkom rječniku na gotovo dvije tisuće stranica. Kako je već Žepić (1992) primijetio, Jambrešić-Sušnikov se rječnik podudara s Kirschevim u simbolima. I Kirsch označuje križićem barbarizme, a zvjezdicom riječi grčkoga podrijetla pa je ta podudarnost jedan od Žepićevih argumenata da je Kirsch bio dvojici isusovaca glavni izvor. Pregledali smo još dva rječnika koji se spominju kao mogući Jambrešić-Sušnikovi izvori - Frisiusa (1700) i Facciolatija (1778), kod kojih nisu pronađene slične odrednice, odnosno simboli pa se Žepićevo (1992) mišljenje drži vjerojatnim. Kirsch uz te simbole ima i druge odrednice, najčešće kratice kojima označuje citirane autore, gramatički opis natuknica i dr. Primijetili smo razliku u tome što Kirsch zastarjelice označuje kraticom Obsol., a Jambrešić i Sušnik s više kratica kao što smo vidjeli. Zanimljivo je usput spomenuti i da je rječniku dodan rimski kalendar, prozodija i mnogi toponimi kao što je i u hrvatskom rječniku. Usporedimo dvije jednake natuknice iz Jambrešić-Sušnikova i Kirscheva rječnika.

${ }^{*}$ Paronychia, ae, $f$. Paronychium, ii, $n$. Plin. Zanobticza, otok nobteni, kurje oko. Ein bös Nagel - Geschvvär, Hüner - Aug. Kºrom méreg, Láb-uj feltºrése, tsomózása (Jambrešić-Sušnik 1992, 672).

${ }^{*}$ Paronychia, ae. f. (Paronychium, ii. n.) der Wurm / ein bös Nagel Geschwär an Fingern oder Zehen /Hüner - Aug / Leichdorn. Plin. 2.) Nagel-Kraut / Mauer-Rauten (Kirsch 1718, 785).

Oba su rječnika označila isti leksem zvjezdicom, odnosno da je grčkoga podrijetla, a podudaraju se i neka značenja. Kirsch ima bogatiji rječnički članak s više značenja, no moramo imati na umu da je Kirschev rječnik dvojezičan, i to na gotovo dvije tisuće stranica, dok je Jambrešić-Sušnikov četverojezičan na pola stranica manje. Međutim, ne postoji potpuna podudarnost između tih dvaju rječnika, i to ne samo u već spomenutim dijelovima. Na istoj smo stranici Kirscheva rječnika pronašli dosta natuknica kojih nema u hrvatskom 
rječniku, što objašnjava obujam, a pronašli smo i iste natuknice koje, na primjer, njemački autor nije označio zvjezdicom, odnosno da su grčkoga podrijetla, a Jambrešić i Sušnik jesu. To govori više stvari. Jedna je da se Jambrešić i Sušnik sigurno nisu koristili samo tim rječnikom, kao što su to pretpostavili već i Dukat i Žepić, odnosno da je hrvatskim leksikografima za izvor latinske građe možda poslužio neki drugi rječnik s latinskim kao polaznim, vjerojatno neka preradba Calepina, ali i to da su Jambrešić i Sušnik svoj rječnik kompilirali iz više izvora pomno odabirući što su smatrali važnim i potrebnim za svoje čitatelje.

Uz taj smo njemački rječnik za ovu priliku pregledali još neka njemačka i talijanska leksikografska djela. Nećemo detaljno iznositi podatke za svako djelo, već ćemo iznijeti rezultate istraživanja i zaključna razmatranja. Pregledan je takozvani turinski rječnik, pretpostavljeni Stullijev uzor, potom Calderinijeva i Facciolatijeva preradba Calepina, Frisiusov latinsko-njemački i njemačko-latinski rječnik, dva izdanja Cruscina rječnika, kao i poljski rječnik Grgura Cnapija (Grzegorz Knapski) iz 17. stoljeća koji Stulli navodi u popisu svojih izvora. Neki od autora daju upute o korištenju rječnika, a neki ne daju. Svi pregledani rječnici imaju neki oblik leksikografskih odrednica, s tim da neki imaju samo kratice, a neki uz kratice i simbole. Upotrebljavaju se i simboli koji nisu leksikografske odrednice poput simbola koji često služi za odvajanje dijelova rječničkoga članka. U svim smo pregledanim rječnicima pronašli kratice kojima se natuknička riječ označuje gramatički, terminološki i tako dalje. Oni koji donose simbole, obično ih i objašnjavaju. Od simbola su najčešći zvjezdica i križić, s tim da značenja tih simbola nisu ustaljena. Iako su simboli vrlo praktične leksikografske odrednice, u 18. stoljeću nisu zaživjeli svugdje, a nešto su češći u rječnicima sa zapadnoeuropskoga prostora. Primijetili smo da je upotreba odrednica u 18. stoljeću, iako neusustavljena, ipak razvijenija i češća nego što je to u 17. stoljeću.

Sve u svemu, u to je vrijeme kako u Hrvatskoj tako i u Europi, upotreba leksikografskih odrednica bila još prilično neustaljena. Spomenimo još samo jedan primjer koji nema izravne veze s hrvatskom leksikografijom, ali je svakako važan dio europske, englesko-francuski rječnik Abela Boyera iz 1699. godine. Cormier je (2008) pokazala da je Boyer, za to vrijeme posve neobično, imao prilično razrađen sustav leksikografskih odrednica. Koristio se simbolima i kraticama i njihovom kombinacijom te objašnjenjima. Njima je natuknice određivao stilistički, vremenski i tako dalje. Boyer je tako zastarjelice označavao dvostrukim križićem, a običnim križićem razgovornu riječ. U tom kontekstu nije naodmet spomenuti i još jedan poljski rječnik, ovaj put iz 18. stoljeća. Riječ je o opsežnu djelu autora Michela Abrahama 
Trotza (1703-1769) ${ }^{22}$ pod naslovom Nouveau dictionnaire françois, allemand et polonois iz 1744. godine. U njem nalazimo i objašnjenja oznaka i kratica prije samoga rječnika, na francuskom, njemačkom i poljskom jeziku. Od kratica Trotz se koristio uobičajenima poput obs. za zastarjelice. Od oznaka, dakle grafijskih odrednica, koristi se zvjezdicom, te jednostrukim i dvostrukim križićem. Zvjezdicom je označio riječi koje nisu dio uzornoga stila, već više pripadaju razgovornomu stilu. Dvostrukim je križićem označio riječi koje počinju grafemom $h$ koje se izgovora, dok je jednostrukim križićem označio riječi koji počinju grafemom $h$ koji se ne čita. ${ }^{23}$ Dakle, to su još neki primjeri neusustavljenosti značenja simbola kao leksikografskih odrednica u Europi u 18. stoljeću. ${ }^{24}$

\section{Zaključak}

Iz danoga možemo zaključiti kako je jedina stalnica, koja ipak ima pokoji izuzetak, u tome što autori leksikografske odrednice u obliku simbola stavljaju s lijeve strane natuknica, a kratice s desne, odnosno u tijelu rječničkoga članka. Simbolima se možda češće natuknica određuje vremenski, ali to nije pravilo, a za čvrste zaključke nužna su daljnja istraživanja. S vremenom će se simboli kao leksikografske odrednice sve više koristiti, a njihova će se upotreba sve više normirati, iako ni danas ne postoji jedinstveni kriterij za njihovu primjenu. Može se reći da hrvatska leksikografija u 18. stoljeću po različitosti leksikografskih odrednica nije zaostajala za europskom, dapače u nju se posve uklapa, a to je vrlo vjerojatno zahvaljujući europskim uzorima i učenosti svojih sastavljača. Detaljne utjecaje i razvoj leksikografskih strujanja trebalo bi svakako istražiti kako bi se osvijetlili razvoj i dosezi starije hrvatske leksikografije, ali i kako bismo lakše razumjeli suvremena metaleksikografska pitanja.

${ }^{22}$ Ime autora pojavljuje se u nekoliko inačica, $\mathrm{u}$ tekstu navodimo kako stoji na koricama rječnika. Uz tu inačicu, autor se navodi i kao Michał Abraham Troc (usp. Puzynina 2000), a u literaturi se razlikuje i godina rođenja (1689, odnosno 1703).

${ }^{23}$ Samo se na ovom primjeru pokazuje koliko je poljska leksikografija metaleksikografski napredovala u jednom stoljeću. Naime, u Cnapijevu rječniku iz 17. stoljeća nismo naišli na neki uočljiv sustav leksikografskih odrednica, osim uobičajenih gramatičkih za latinski jezik.

${ }^{24} \mathrm{Ni}$ danas upotreba leksikografskih odrednica, posebice grafijskih, nije usustavljena. Usporedi npr. ruski rječnik na http://softacademy.lnpu.edu.ua/Programs/Dictionaries/ Sklyarevskaya.htm ili hrvatski na internetskoj stranici http://hjp.srce.hr/index.php?show=main. 


\section{Primarna literatura}

Bella, Ardelio della, 1728, Dizionario Italiano, Latino, Illirico, Venezia.

Belostenec, Ivan, 1972, Gazophylacium, I. knjiga, pretisak, Liber i Mladost, Zagreb.

Caes a ris Calderini Mirani, 1705, Perfectissimus Calepinus Parvus Sive Corectissimum Dictionarium Caesaris Calderini Mirani, Bassani.

Cnapius, Gregorius, 1626, Thesaurus Polono Latinograeci, Kraków.

Facciolati, Jacobi, 1778, Calepinus septem linguarum hoc est Lexicon Latinum, Tomus primus A-L, Ex Typographia Johaninis Gatti, Veneti.

Frisius, Johann, 1700, Dictionarium bilingue Latino-Germanicum, et Germanico-Latinum, Tiguri.

Ja mbrešić, Andrija, Sušnik, Franjo, 1992, Lexicon latinum, pretisak, Zavod za hrvatski jezik, Zagreb.

Kirsch, Adam Friedrich, 1718, Abudantissimum Cornu Copiae Linguae Latinae et Germanicae selectum, Noribergae.

Relković, Matija Antun, 1767, Nova Slavonska i Nimacska grammatika, Zagreb.

Stulli, Joakim, 1801a, Lexicon Latino-Italico-Illyricum, I. svezak, Budim.

Stulli, Joakim, 1801b, Lexicon Latino-Italico-Illyricum, II. svezak, Budim.

Trotz, Michel Abraham, 1744, Nouveau dictionnaire françois, allemand et polonois, Leipzig.

Vocabolario degli Acacdemici della Crusca compendiato da un Accademico Animoso, Volume primo A-N, 1734, Venezia.

Vocabolario degli Accademici della Crusca, A - C, 1763, Volume Primo, Venezia.

Vocabolario Italiano et Latino diviso in due tomi ... per uso degli studiosi di Belle Lettere nella regia Universita di Torino, 1751, Tomo primo, Napoli.

Vocabula Latini, Italique sermonis in duos tomos distributa ... ad usum Studiosae Humnaorum Litterarum Juventutis in regio Taurinensi Archigymnasio, 1761, Tomus alter, Neapoli.

http://hjp.srce.hr/index.php?show=main (Pristupljeno 14. prosinca 2011.)

http://softacademy.lnpu.edu.ua/Programs/Dictionaries/Sklyarevskaya.htm (Pristupljeno 14. prosinca 2011.)

\section{Sekundarna literatura}

Agičić D., i dr., ur., 2000, Matija Antun Relković i Slavonija 18. stoljeća, Zagreb.

Babić Stj., 1981, Stilske odrednice u našim rječnicima, „Jezik” 3 (28), 79-91.

Brata nić-Či mbur M., 1979, Prilog za dvojezičnu leksikografsku teoriju, „Jezik” 1 (27), 1-9.

Brlek M., 1987, Leksikograf Joakim Stulli (1730-1817) [„Djela JAZU” 60], Zagreb.

Brlobaš Ž., 2003, Gramatičke odrednice u Rječniku hrvatsko-talijanskom (1901) Dragutina

Parčića, „Rasprave Instituta za hrvatski jezik i jezikoslovlje” 29, 9-20. 
Cormier M. C., 2008, Usage Labels in the Royal Dictionary (1699) by Abel Boyer, „International Journal of Lexicography" 21, 2, 153-171.

D e mo Š., 2004, Latinska sintaksa kao implicitno prisutna problematika u gramatikama Tome Babića i Lovre Šitovića, „Fluminensia” 16, 1-2, 45-63.

Despot L., 2005, Jezik slavonskih franjevaca (do preporoda), Osijek.

D u kat V., 1905, Jambrešićev ,Lexicon latinum', „Rad JAZU” 162, 192-234.

D u kat V., 1923, Izvori Belostenčeva ,Gazophylacium latino-illyricum', „Rad JAZU” 227, 80-109.

Dukat V., 1925, O izvorima Jambrešićeva rječnika, „Nastavni vjesnik” 33, 17-20, 54-58.

Du kat V., 1928, O kompoziciji i vrelima Belostenčeva ,Gazophylacium illyrico-latinum', „Rad JAZU” 235, 1-25.

Dukat V., 1929, Dubrovačko izdanje Dellabellina ,Dizionarija', „Rad JAZU” 237, 235-272.

Engler R., 2000, Die Accademia della Crusca und die Standardisierung des Italienischen, [u:] S. Auroux, E. F. K. Koerner, H. J. Niederehe, K. Versteegh, ur., History of Language Sciences, Vol. 1, Berlin - New York, 815-827.

Fancev F., 1923, O postanju iliričko-latinskoga dijela Belostenčeva Rječnika, „Prilozi za književnost, jezik, istoriju i folklor" 3, 150-165.

Gostl I., 1998, Leksička građa u latinsko-hrvatskoj gramatici Lovre Šitovića, „Kolo” 4, 106-122.

Hartman n R. R. K., ur., 1986, The History of Lexicography [„Amsterdam Studies in the history of the language sciences" 40], Amsterdam - Philadelphia.

Hartmann R. R. K., Gregory J., 2002, Dictionary of Lexicography, London - New York.

Häu sler M., 1992, Udžbenici njemačkog jezika u Hrvatskoj 18. stoljeća, magistarski rad, rkp. Zagreb.

Häusler M., 2002, Od Komenskog do novih medija - Vizualna sredstva u nastavi stranih jezika, „Strani jezici” 31, 1-2, 21-34.

Jembrih A., 1990, Hrvatski filološki aspekti, Čakovec - Osijek.

Jonke Lj., 1966, Hrvatsko-njemački jezični priručnik Blaža Tadijanovića iz 1761, „Kolo” 6 (3-4), 301-309.

Katičić R., 1991, Sintaksa hrvatskoga književnog jezika, Zagreb.

Knezović P., 1988, Aneksni rječnici latinskih gramatika 18. stoljeća, [u:] A. Peco, ur., „Leksikografija i leksikologija” 21, Sarajevo, 143-154.

Knezović P., ur., 2002, Zbornik o Tomi Babiću, Šibenik - Zagreb.

Knezović P., Demo Š., 2003, Pogovor, [u:] Šitović L., Grammatica Latino-Illyrica..., pretisak, Sarajevo - Zagreb - Ljubuški, 300-316.

Knezović P., ur., 2009, Zbornik o Lovri Šitoviću, Zagreb.

Kolenić Lj., 2000, Rječnik Tome Babića i hrvatski pojmovni rječnik, „Fluminensia” 12, 1-2, 37-44.

Kolenić Lj., prir., 2003, Brodski jezikoslovci: Djelomični pretisci gramatika Blaža Tadijanovića, Marijana Lanosovića i Ignjata A. Brlića s komentarima, Slavonski Brod.

Ko sor K., 1981, Hrvatski jezik latinske gramatike fra Tome Babića, „Kačić” 13, 5-56.

Ko sor M., 1953, Trojezična gramatika fra Josipa Jurina, „Rad JAZU” 295, 41-65.

Kos or M., 1955, Zaboravljeni trojezičnici Josipa Jurina, „Rad JAZU” 303, 119-210. 
Ko sor M., 1957, Izvori, pravopis i jezik Jurinovih rječnika, „Rad JAZU” 315, 77-231.

Košutar P., Tafra B., 2010, Hrvatske akademije (od 16. do 18. stoljeća) u europskom kontekstu, „Kroatologija” 1, 1, 131-148.

Kuna H., 1961, Neke osobine jezika fra Lovre Šitovića, „Građa” 10, 125-177.

Matković M., Tadija nović D., ur., 1981, Zborniko Vidu Došenu i Blažu Tadijanoviću, Osijek.

Musulin Stj., 1959, Hrvatska i srpska leksikografija, „Filologija” 2, 41-63.

Nyomárkay I., 1992, Mađarska građa u Jambrešićevu rječniku, [u:] Ja mbrešić A., Sušnik F., Lexicon Latinum interpretatione illyrica ..., pretisak, Zagreb, LI-LIII.

Nyomárkay I., 2000, Kroatističke studije, Zagreb.

Petrović B., 2002, Uputnice u dvojezičnicima s hrvatskim kao polaznim jezikom, „Filologija” 38-39, 125-135.

Ptičar A., 1985, Latinska gramatika Marijana Lanosovića, [u:] D. Tadija nović, Đ. Berber, ur., Zbornik radova o Marijanu Lanosoviću, Osijek, 175-178.

Putanec V., 1981, Prilog Blaža Tadijanovića francusko-hrvatskoj leksikografiji, [u:] M. Matković, D. Tadija nović, ur., Zbornik radova o Vidu Došenu i Blažu Tadijanoviću, Osijek, 107-110.

Putanec V., 1994, Sigliranje identičnih definicijskih formula u jednojezičnoj leksikografiji, „Filologija” 22-23, 351-353.

Puzynina J., 2000, Normative studies in Poland, [u:] S. A u roux, E. F. K. Koerner, H. J. Nied erehe, K. Versteegh, ur., History of Language Sciences, Vol. 1, Berlin-New York, 912-916.

Raguž D., 1978, Jezik Lovre Ljubušaka (Šitovića), rkp. magistarska radnja u NSK, Zagreb.

Sironić-Bonefačić N., 1990, Nastanak i izvori Della Bellina rječnika (Dizionario italiano, latino, illirico, Venezia, 1728), [u:] D. Ši mundža, ur., Isusovac Ardelio della Bella (1655-1737), Split - Zagreb, 23-49.

Sironić-B on efačić N., 1992, Ardelio della Bella i prvo izdanje njegova trojezičnog rječnika iz 1728., „Rad HAZU” 446, 1-69.

Šetka J., 1967, O. Fra Toma Babić, „Kačić” 1, 95-203.

Šimundža D., ur., 1990, Isusovac Ardelio della Bella (1655-1737), Split - Zagreb.

Šipka D., 1998, Osnovi leksikologije i srodnih disciplina, Novi Sad.

Šojat A., 1992, Latinsko-hrvatsko-njemačko-madžarski rječnik Franje Sušnika i Andrije Jambrešića, [u:] Ja mbrešić A., Sušnik F., Lexicon Latinum interpretatione illyrica ..., pretisak, Zagreb, III-XXVIII.

Štefa nić Vj., 1940, Prilog za sudbinu Alvaresove latinske gramatike među Hrvatima, „Vrela i prinosi" $11,26-34$.

Tadija nović D., Đ. Berber, ur., 1985, Zbornik radova o Marijanu Lanosoviću, Osijek.

Tadijanović D., J. Vončina, ur., 1991, Vrijeme i djelo Matije Antuna Reljkovića, Osijek.

Tafra B., 1981, O jeziku Blaža Tadijanovića, [u:] M. Matković, D. Tadijanović, ur., Zbornik radova o Vidu Došenu i Blažu Tadijanoviću, Osijek, 99-105.

Tafra B., 1990, Mjesto Della Belline gramatike u povijesti hrvatskih gramatika, „Rasprave Zavoda za jezik" 16, 263-274. 
Tafra i Fink, 2008: Тафра Б., Ж. Фин к, 2008, Хорватская лексикография, [u:] „Теория и история славянской лексикографии (научные материалы к XIV съезду славистов), Международный комитет славистов, Комиссия по лексикологии и лексикографии, Национальный комитет славистов РФ, Учреждение РАН, Институт русского языка им. В. В. Виноградова РАН”, ред. М. И. Чернышев а, Москва, 220-244.

Tikvica Lj., 2009, Lingvostilističke odrednice u rječnicima hrvatskoga jezika. O nekim poteškoćama stilističkoga označivanja u jezikoslovnoj leksikografiji, „Studia lexicographica” 3, 1-2 (4-5), 5-13.

Vončina J., 1973, Leksikografski rad Ivana Belostenca, [u:] Belostenec I., Gazophylacium, II. knjiga, pretisak, Zagreb, III-LXVII.

Zgusta L., 1991, Priručnik leksikografije, prev. D. Šipka, Sarajevo.

Žepić S., 1992, Njemački dio u Sušnik-Jambrešićevu,Lexicon Latinum', [u:] Ja mbrešić A., Sušnik F., Lexicon Latinum interpretatione illyrica ..., pretisak, Zagreb, XXIX-L.

Žepić S., 1998, Deutsche Grammatiken kroatischer Verfasser in der zweiten Hälfte des 18. Jahrhunderts, „Schriften zur deutschen Sprache in Österreich” 24, 10-94.

\section{European Models for the Croatian Language Handbooks in the $18^{\text {th }}$ Century}

\section{(Summary)}

Until the $19^{\text {th }}$ century Croatian language handbooks, namely grammars, dictionaries and ortography books, were mostly bilingual and multilingual. Only at the begining of the $19^{\text {th }}$ century was the first grammar of Croatian written in Croatian published, and in the second half of the same century the first monolingual dictionary - Academy's Dictionary was published. The origin of this is not in the language itself. When writing these multilanguage handbooks, the authors followed domestic predecessors, as well as foreign. This work is an attempt to reveal those foreign language models that Croatian linguists in the $18^{\text {th }}$ century followed and on the example of one metalexicographic theme - usage labels - to show developoment of Croatian $18^{\text {th }}$ century lexicography within the European lexicography. 